\title{
Characteristics of Lignin Fractions from Dilute Acid Pretreated Switchgrass and Their Effect on Cellobiohydrolase from Trichoderma longibrachiatum
}

OPEN ACCESS

Edited by:

Rongxin Su,

Tianjin University, China

Reviewed by:

Tae Hyun Kim,

Hanyang University, South Korea

Luis Serrano,

Universidad de Córdoba, Spain

*Correspondence:

Arthur J. Ragauskas

aragausk@utk.edu

Specialty section:

This article was submitted to

Bioenergy and Biofuels,

a section of the journal

Frontiers in Energy Research

Received: 30 November 2017

Accepted: 19 January 2018

Published: 06 February 2018

Citation:

Yao $L$, Yang $H$, Yoo CG, Meng $X$ Pu Y, Hao N and Ragauskas AJ (2018) Characteristics of Lignin

Fractions from Dilute Acid

Pretreated Switchgrass and Their

Effect on Cellobiohydrolase from Trichoderma longibrachiatum.

Front. Energy Res. 6:1.

doi: 10.3389/fenrg.2018.00001

\author{
Lan $\mathrm{Yao}^{1,2,3}$, Haitao Yang ${ }^{1,2}$, Chang Geun $\mathrm{Yoo}^{4}$, Xianzhi Meng ${ }^{3}$, Yunqiao $\mathrm{Pu}^{3}, \mathrm{Naijia} \mathrm{Hao}^{3}$ \\ and Arthur J. Ragauskas ${ }^{3,4,5 *}$
}

${ }^{1}$ Hubei Provincial Key Laboratory of Green Materials for Light Industry, Hubei University of Technology, Wuhan, China, ${ }^{2}$ State Key Laboratory of Pulp and Paper Engineering, South China University of Technology, Guangzhou, China, ${ }^{3}$ Department of Chemical and Biomolecular Engineering, The University of Tennessee, Knoxville, TN, United States, ${ }^{4}$ Joint Institute for Biological Sciences, Biosciences Division, Oak Ridge National Laboratory (ORNL), Oak Ridge, TN, United States, ${ }^{5}$ Department of Forestry, Wildlife and Fisheries, Center for Renewable Carbon, Institute of Agriculture, The University of Tennessee, Knoxville, TN, United States

To investigate the interactions between acid pretreated switchgrass lignin and cellobiohydrolase $(\mathrm{CBH})$, three different lignin fractions were isolated from dilute acid pretreated switchgrass by (i) ethanol extraction, followed by (ii) dioxane/ $\mathrm{H}_{2} \mathrm{O}$ extraction, and (iii) cellulase treatment, respectively. Structural properties of each lignin fraction were elucidated by GPC, ${ }^{13} \mathrm{C}-\mathrm{NMR}$, and 2D-HSQC NMR analyses. The adsorptions of $\mathrm{CBH}$ to the isolated lignin fractions were also studied by Langmuir adsorption isotherms. Ethanolextractable lignin fraction, mainly composed of syringyl (S) and guaiacyl (G) units, had the lowest molecular weight, while dioxane/ $\mathrm{H}_{2} \mathrm{O}$-extracted lignin fraction had the lowest $S / G$ ratio with higher content of $p$-coumaric acid $(p C A)$ unit. The residual lignin fraction after enzymatic treatment had the highest $S / G$ ratio without hydroxyphenyl $(H)$ unit. Strong associations were found between lignin properties such as lignin composition and $S / G$ ratio and its non-productive enzyme adsorption factors including the maximum adsorption capacity and binding strength.

Keywords: characterization, lignin, dilute acid pretreatment, switchgrass, cellobiohydrolase

\section{INTRODUCTION}

Rapid population growth and energy security concerns associated with fossil fuels have led to the development in alternative energy resources like biofuels (Cao et al., 2012). Second-generation biofuel produced from energy crops, agricultural, and forestry residues can avoid competition with food resources, thus it is a promising alternative fuel technology (Yan et al., 2010). Switchgrass has been considered as a potential feedstock for bioethanol production due to its high net energy content, low production costs, low nutrient necessity, high water utilization efficiency, and high pests and diseases tolerance (Samuel et al., 2010).

Pretreatment is an essential step for effective biological conversion of biomass to bioethanol. Diverse pretreatment technologies have been introduced to reduce biomass recalcitrance (Li et al., 2014). Among various pretreatment methods, dilute acid pretreatment has been widely investigated and applied, which typically employing a low concentration of $\mathrm{H}_{2} \mathrm{SO}_{4}(<4 \%)$ at moderate 
temperatures $\left(140-220^{\circ} \mathrm{C}\right)$ (Galbe and Zacchi, 2007; Yao et al., 2010). Compared to other pretreatment methods, by now, this pretreatment method is close to practical application in industrial production due to low chemical cost and utilization with diverse biomass feedstocks including hardwood and agricultural residues (Benjamin et al., 2013; Mesa et al., 2017). Typically, pretreated biomass is then subjected to enzymatic hydrolysis to produce glucose via a mixture of enzymes such as endoglucanase (EG), exoglucanase or cellobiohydrolases ( $\mathrm{CBHs}$ ), and $\beta$-glucosidase (Abraham et al., 2014). CBHs are a group of cellulases that can hydrolyze glycosidic linkages at a crystalline surface of cellulose (Igarashi et al., 2009). In particular, CBH I (TrCel7 A) is one of the most abundant enzymes secreted by Trichoderma reesei. It was reported that Cel7A showed higher hydrolytic power than other T. reesei enzymes involving cellulose hydrolysis (Yan et al., 2011). In recent years, researches have focused on $\mathrm{CBH}$ binding to lignin. Palonen et al. found that CBH I exhibited a higher adsorption affinity to lignin than EG II from $T$. reesei (Palonen et al., 2004). Strong bindings of Trichoderma reesei CBH-I and EG-I to both cellulose and lignin were observed using quartz crystal microgravimetry (Martín et al., 2013). Other studies reported that the cellulose binding domain of the effluent enzyme played a significant role in the unspecific binding of cellulases to lignin (Palonen et al., 2004; Rahikainen et al., 2013; Strobel et al., 2015, 2016). T. longibrachiatum, which are taxonomically separable from T. reesei, could also act as a potential cellulase candidate with high activities (Kubicek et al., 1996).

Lignin is the most abundant non-carbohydrate component in plant cell walls and is considered a leading contributor involved in biomass recalcitrance. Lignin is typically derived from three hydroxycinnamyl alcohols (monolignols) that include $p$-coumaryl, coniferyl, and sinapyl alcohols which are connected via various types of linkages including aryl ether and carbon-carbon bonds (Ralph et al., 2004; Ragauskas et al., 2014). It is widely accepted that lignin inhibits enzymatic hydrolysis of lignocellulosic biomass (Zeng et al., 2014; Lu et al., 2016; Saini et al., 2016; Yang et al., 2016). The adsorption of enzymes onto isolated lignins from dilute acid or hot water pretreated biomass has been studied (Zheng et al., 2013; Yu et al., 2014; Li et al., 2016; Lu et al., 2016; Sun et al., 2016). They reported key lignin-enzyme binding effects including the effects of condensed phenolic $\mathrm{OH}$ groups, methoxy groups, and the degree of lignin condensation on cellulase binding.

The difficulty in elucidating the mechanism of cellulase adsorption to lignin is partly due to the structural complexity of lignin. Thus, a method to fractionate lignin and get lignin fractions with distinctive structure is needed. Lignin fractionation using different hydrogen-bonding capacity organic solvents was introduced to elucidate structural properties of lignin (Mörck et al., 1986, 1988; Yuan et al., 2009). In order to fractionate lignin with various properties that might affect its adsorption capabilities to enzymes, in this study, three different lignin fractions were separated from the dilute acid pretreated switchgrass using ethanol extraction (Fraction NO.1 lignin), followed by $96 \%$ dioxane extraction (Fraction NO.2 lignin), and then overloading with cellulase to recover lignin residue (Fraction NO.3 lignin). Characteristics of each lignin fraction were analyzed by gel permeation chromatography (GPC), ${ }^{13} \mathrm{C}$-nuclear magnetic resonance (NMR) and 2D-heteronuclear single quantum coherence (HSQC) NMR. Non-productive enzyme adsorption factors of lignin were evaluated by measuring the adsorption of $\mathrm{CBH}$ to lignin samples. The correlations between physicochemical characteristics of lignin and lignin-enzyme adsorption parameters were also discussed.

\section{EXPERIMENTAL}

\section{Materials}

Samples of the lowland cultivar Alamo switchgrass (Panicum virgatum), which were grown in 2011 and harvested in 2012 were provided by the Samuel Roberts Noble Foundation in Ardmore, OK. The chemical reagents were purchased from Fisher Scientific (USA) and used as received without further purification unless otherwise specified. Protease (Cat. No. 10165921001) was purchased from Sigma Chemical Company (USA), and CBH (Cat. No. 37329-65-0) was purchased from Megazyme (Ireland).

\section{Dilute Acid Pretreatment of Switchgrass}

The biomass sample was Wiley-milled through a $2 \mathrm{~mm}$ screen and then extracted by toluene/ethanol $(2: 1, v / v)$ for $8 \mathrm{~h}$, followed by water and acetone for $3 \mathrm{~h}$ per each extraction to remove extractives (Hao et al., 2017). The extractive-free material was loaded to a 1 L 4560 Parr reactor (Parr Instrument Company, Moline, IL, USA) with $1 \%$ sulfuric acid $(v / v)$ solution at a $10 \%$ solid loading $(w / w)$. The pretreatment temperature was set at $150 \pm 2{ }^{\circ} \mathrm{C}$ and kept for $10 \mathrm{~min}( \pm 0.5 \mathrm{~min})$, which was the optimum dilute-acid pretreatment condition for switchgrass in the previous study (Zhou et al., 2012). The stirring speed was $2.5 \mathrm{~Hz}$ and the heating rate was $3^{\circ} \mathrm{C} / \mathrm{min}$. To stop the pretreatment process, the Parr reactor was quenched in an ice water bath. The pretreated switchgrass was seperated and washed with deionized water until the effluent $\mathrm{pH}$ was neutral, then the biomass was air-dried overnight. The yield for pretreatment was $43 \%$ by mass of the initial substrate.

\section{Fractionation of Lignin from Pretreated Switchgrass}

Lignin fractions were separated from dilute acid pretreated switchgrass as shown in Figure 1. The detailed method was the same as described in a previous study (Yao et al., 2017). In brief, the pretreated switchgrass was first extracted with anhydrous ethanol (liquid:solid = 10:1) for $24 \mathrm{~h}(\times 2)$ and ethanol-solved lignin fraction was purified as NO.1 lignin. The air-dried solid residues after ethanol extraction was treated by $96 \%$ dioxane $(v / v)$ to get the dioxane-water soluble lignin (NO.2 lignin). The last lignin fraction was obtained by over-loading cellulase hydrolysis of the solid residues followed by $96 \%$ dioxane $(v / v)$ extraction. Each lignin fraction was purified according to the milled wood lignin method (Björkman, 1956). The relative quantity of each lignin fraction was $62.6,35.4$, and $2.0 \%$.

\section{Analysis Procedures Chemical Composition Analysis}

Lignin and carbohydrate contents were determined according to the National Renewable Energy Laboratory procedure (Sluiter 


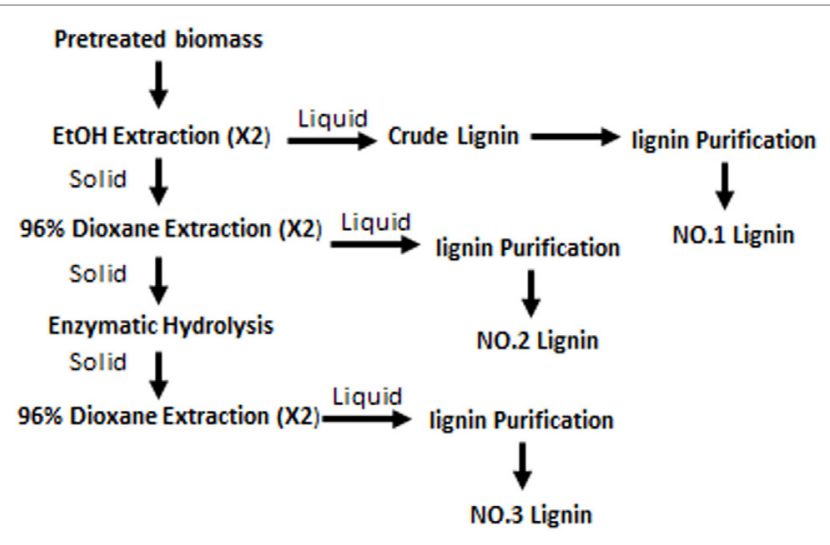

FIGURE 1 | Fractionation of lignin from dilute-acid pretreated switchgrass.

et al., 2008) and analyzed by a high-performance anion exchange chromatography (Dionex, ICS 3000, Sunnyvale, CA, USA), as described in a previous study (Meng et al., 2013).

\section{GPC Analysis}

The molecular weights of each lignin fraction was measured with GPC analysis after acetylation of lignins (Kumar et al., 2013). GPC was performed on an Agilent 1200 HPLC system (Agilent Technologies, Inc, Santa Clara, CA, USA).

\section{NMR Analysis}

About $50 \mathrm{mg}$ of lignin samples were dissolved in deuterated dimethyl sulfoxide (DMSO- $d_{6}, 0.4 \mathrm{~mL}$ ). Two-dimensional (2D) ${ }^{1} \mathrm{H}-{ }^{13} \mathrm{C}$ HSQC NMR experiment was conducted at $298 \mathrm{~K}$ using a Bruker Advance III 400-MHz spectroscopy (5-mm BBO $400 \mathrm{MHz}$ W1 with Z-gradient probe, Bruker). A Bruker standard pulse sequence ("hsqcetgpsi2") was used. Operation parameters were obtained from a previous study (Yoo et al., 2017).

${ }^{31} \mathrm{P}$ NMR spectra were obtained after derivatization of the lignin fractions by 2-chloro-4,4,5,5-tetramethyl-1,3,2-dioxaphospholane. Endo N-hydroxy-5-norbene-2,3-dicarboxylic acid imide was prepared as the internal standard. The spectral acquistion parameters for ${ }^{31} \mathrm{P}$ NMR spectra were as follows: a $90^{\circ}$ pulse angle, 25 -s pulse delay, and 256 transients at room temperature.

\section{Adsorption of $\mathrm{CBH}$ to Lignin}

Prior to conducting the adsorption test, soluble impurities in the lignin fraction was removed with acetate buffer $(50 \mathrm{mM}, \mathrm{pH}$ 4.8 ) at $50^{\circ} \mathrm{C}$ for $12 \mathrm{~h}$. CBH (Megazyme, Wicklow, Ireland), from Trichoderma longibrachiatum, was supplied at $10 \mathrm{mg}$ protein/ $\mathrm{mL}$. The adsorption of $\mathrm{CBH}$ to the lignins was measured by the Langmuir isotherm. A range concentration of $\mathrm{CBH}(0.1-10.0 \mathrm{mg} /$ $\mathrm{mL})$ was mixed with lignin fractions $(2 \%, w / v)$ suspended in $50 \mathrm{mM}$ sodium acetate buffer ( $\mathrm{pH} 4.8$ ). The mixture was kept at $50^{\circ} \mathrm{C}$ with $150 \mathrm{rpm}$ shaking for $4 \mathrm{~h}$ to reach the equilibrium. Lignin in acetate buffer $(2 \%, w / v)$ and the same concentration of $\mathrm{CBH}$ were used as the controls. The protein concentration was determinated by Pierce ${ }^{\mathrm{TM}}$ bicinchoninic acid protein assay from Thermo scientific. The adsorption parameters, such as $E_{\max }$ and
TABLE 1 | Weight-average $\left(M_{w}\right)$, number-average $\left(M_{n}\right)$ molecular weights and polydispersity indexes $\left(M_{\mathrm{w}} / M_{\mathrm{n}}\right)$ of the three lignin samples.

\begin{tabular}{lccc}
\hline Samples & $\begin{array}{c}\boldsymbol{M}_{\mathbf{n}} \\
\mathbf{g} / \mathbf{m o l}\end{array}$ & $\begin{array}{c}\boldsymbol{M}_{\mathbf{w}} \\
\mathbf{g} / \mathbf{m o l}\end{array}$ & $\boldsymbol{M}_{\mathbf{w}} / \boldsymbol{M}_{\mathbf{n}}$ \\
\hline NO.1 lignin & $1,511 \pm 50$ & $2,277 \pm 75$ & $1.51 \pm 0.00$ \\
NO.2 lignin & $2,177 \pm 71$ & $3,551 \pm 85$ & $1.63 \pm 0.01$ \\
NO.3 lignin & $2,187 \pm 74$ & $3,284 \pm 93$ & $1.51 \pm 0.01$
\end{tabular}

TABLE 2 | Chemical composition of three lignin samples.

\begin{tabular}{lccc}
\hline Samples & Acid insoluble lignin $\%$ & Glucose $\%$ & Total\% \\
\hline NO.1 lignin & 89.35 & 0.20 & 89.55 \\
NO.2 lignin & 90.20 & 0.15 & 90.35 \\
NO.3 lignin & 90.02 & 0.20 & 90.22 \\
\hline
\end{tabular}

$K_{\text {ads }}$ were obtained by linear regression of the adsorption data by the following Equation.

$$
\frac{\left[E_{f}\right]}{[E]}=\frac{1}{K_{\mathrm{ads}}\left[E_{\max }\right]}+\frac{\left[E_{f}\right]}{\left[E_{\max }\right]}
$$

where $\left[E_{f}\right](\mathrm{mg} / \mathrm{mL})$ is the free protein concentration at equilibrium, $[E](\mathrm{mg} / \mathrm{mg})$ is the amount of protein adsorbed by lignin, $K_{\text {ads }}$ is Langmuir adsorption constant, and $\left[E_{\max }\right]$ is the maximum amount of adsorbed protein.

\section{RESULTS AND DISCUSSION}

\section{Molecular Weight and Chemical Composition of Lignin}

Table 1 presents molecular weights of three lignin fractions isolated from dilute acid pretreated switchgrass. Molecular weights of these lignins were lower than the values of untreated switchgrass in the previous study $[5,000 \mathrm{~g} / \mathrm{mol}$ of weight average molecular weight $\left(M_{\mathrm{w}}\right)$ and $2,940 \mathrm{~g} / \mathrm{mol}$ of number average molecular weight $\left(M_{\mathrm{n}}\right)$, respectively] (Samuel et al., 2010). It indicated that these lignin fractions extracted was depolymerized during the dilute acid pretreatment. In addition, slightly lower polydispersity indexes of the three lignin samples (1.51-1.63) were observed as compared to that of initial lignin from untreated sample (1.70), suggesting a narrower molecular weight distribution of these lignins. In specific, the weight average molecular weight of the NO.1 lignin extracted by ethanol was $2,277 \mathrm{~g} / \mathrm{mol}$, which represents the lowest molecular weight among all three fractions, while the NO.2 and NO.3 lignin fractions had higher Mw (3,551 and 3,284 $\mathrm{g} / \mathrm{mol}$, respectively).

The carbohydrate and lignin content of the three lignin fractions are presented in Table 2 . The results showed that the acid insoluble lignin contents were $90 \%$ for all three lignin samples with small quantity of glucose. There were no significant compositional differences among the three lignin fractions.

\section{${ }^{13} \mathrm{C}$ NMR Analysis}

NMR is a well-established analytical tool to observe lignin structures (Capanema et al., 2004). To compare the characteristic 


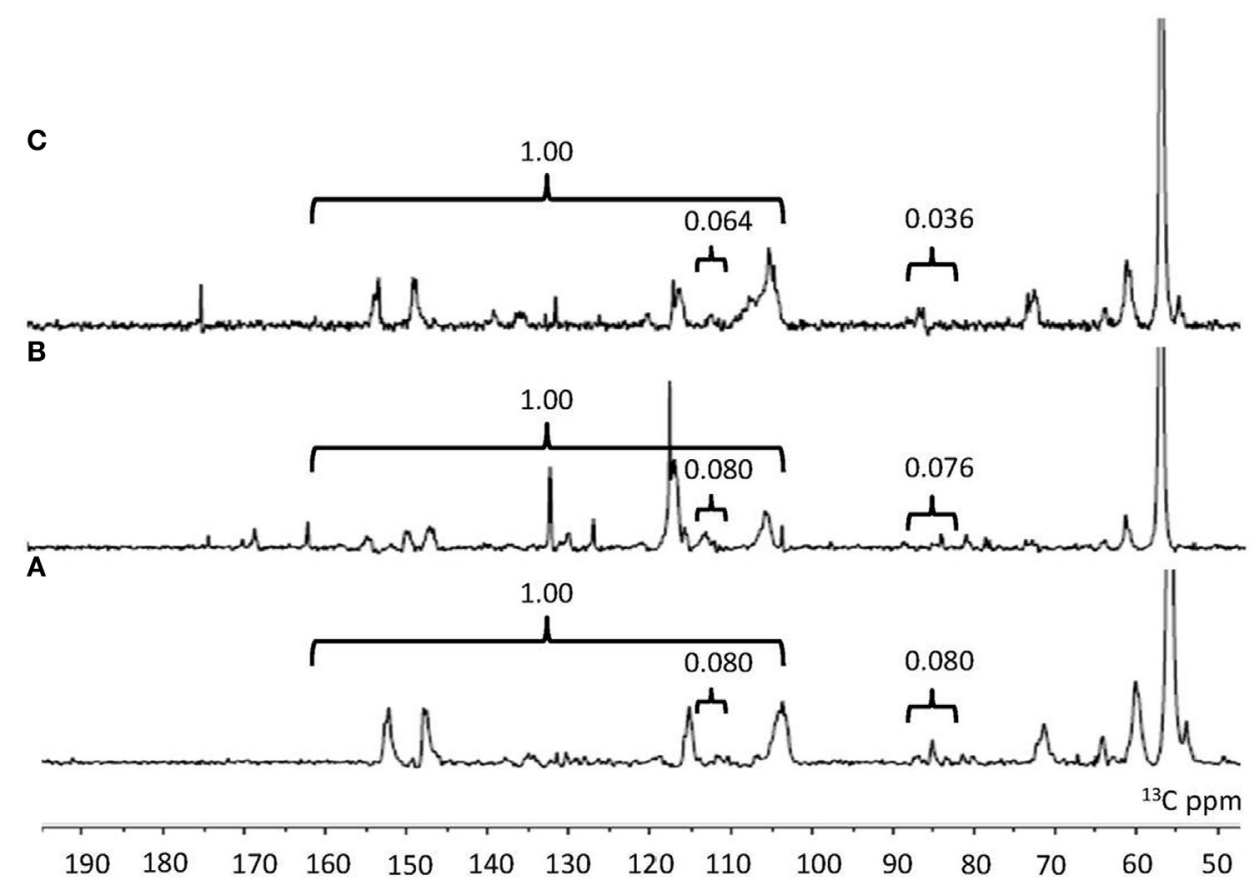

FIGURE $2 \mid{ }^{13} \mathrm{C}-\mathrm{NMR}$ spectra and integration value of lignin samples (A) NO.1 lignin. (B) NO.2 lignin. (C) NO.3 lignin. $160-102$ ppm in the quantitative ${ }^{13} \mathrm{C}$ nuclear magnetic resonance was representative of the total carbon atoms from all aromatic rings within the lignin. 119-113 and 88-82 ppm was used as internal standard in the aromatic and aliphatic region.

of the isolated lignin samples, quantitative ${ }^{13} \mathrm{C}$ NMR was carried out. ${ }^{13} \mathrm{C}$-NMR spectra of lignin samples are shown in Figure 2. The assignments of signals are listed in Table 3. In the aromatic region, the signals were mainly from guaiacyl $(G)$, syringyl (S) and $p$-hydroxyphenyl $(\mathrm{H})$. It was facile to assign signals for these three substructures in NO.1 and NO.2 lignin at $128.9 \mathrm{ppm}\left(\mathrm{C}_{2 / 6}\right.$ in $p$-hydroxyphenyl), $115.0 \mathrm{ppm}\left(\mathrm{C}_{5}\right.$ in guaiacyl), and $104.0 \mathrm{ppm}$ $\left(\mathrm{C}_{2 / 6}\right.$ in syringyl) (Yang et al., 2016). The signal at $\sim 173.9 \mathrm{ppm}$ assigned for $\mathrm{C}=\mathrm{O}$ was absent in NO. 1 and 2 lignin. In the aliphatic region, the signals from $-\mathrm{OCH}_{3}$ at $55.8 \mathrm{ppm}, \beta-O-4^{\prime}$ at around $72.3 \mathrm{ppm}\left(\mathrm{C} \alpha\right.$ in $\left.\beta-O-4^{\prime}\right), 85.2 \mathrm{ppm}\left(\mathrm{C} \beta\right.$ in $\mathrm{S}$ type $\left.\beta-O-4^{\prime}\right)$ and $60.1 \mathrm{ppm}\left(\mathrm{C} \gamma\right.$ in $\left.\beta-O-4^{\prime}\right), \beta-5$ at about $86.8 \mathrm{ppm}(\mathrm{C} \alpha)$ and $\mathrm{C} \gamma$ in $\beta-\beta^{\prime}$ at $\sim 71.7 \mathrm{ppm}$ (Samuel et al., 2010; Strobel et al., 2016) were readily assigned.

\section{Structural Information of Lignin Fractions using 2D-HSQC NMR Analysis}

HSQC is the most applied 2D NMR techniques for the structure determination of lignin samples with enhanced spectral resolution. HSQC spectra of aromatic and aliphatic regions of each lignin fraction from dilute acid pretreated switchgrass are shown in Figure 3. The cross peaks were assigned according to previous studies (Samuel et al., 2010; Hu et al., 2012; Zeng et al., 2013; Yang et al., 2016).

In aromatic region, lignin subunits such as $G, S$, and $H$ units were observed. The spectra indicated that the lignin fractions were mainly enriched in $\mathrm{G}$ and $\mathrm{S}$ units with small contents of $\mathrm{H}$ unit in NO.1 and NO.2 lignin. The ${ }^{13} \mathrm{C}-{ }^{1} \mathrm{H}$ correlation for
TABLE 3 | Signal assignments for the ${ }^{13} \mathrm{C}-\mathrm{NMR}$ spectra of three lignin samples from dilute acid pretreated switchgrass.

\begin{tabular}{|c|c|c|c|}
\hline \multirow[t]{2}{*}{ Assignments } & \multicolumn{3}{|c|}{ Chemical shift (ppm) } \\
\hline & NO.1 lignin & NO.2 lignin & NO.3 lignin \\
\hline$C=O$ & - & - & 173.9 \\
\hline $\mathrm{C}_{3 / 5}$ in syringyl & 152.5 & 152.7 & 152.2 \\
\hline $\mathrm{C}_{3}$ in guaiacyl & 147.8 & 148.0 & 147.5 \\
\hline $\mathrm{C}_{2 / 6}$ in $p$-hydroxyphenyl & 128.9 & 128.9 & - \\
\hline $\mathrm{C}_{6}$ in guaiacyl & - & 111.8 & 119.1 \\
\hline $\mathrm{C}_{5}$ in guaiacyl & 115.4 & 115.1 & 115.9 \\
\hline $\mathrm{C}_{2}$ in guaiacyl & 111.8 & 111.4 & - \\
\hline $\mathrm{C}_{2 / 6}$ in syringyl & 104.1 & 104.1 & 104.0 \\
\hline $\mathrm{C}_{\alpha}$ in $\beta-5$ & 86.8 & 86.8 & 87.1 \\
\hline $\mathrm{C}_{\beta}$ in $\mathrm{S}$ type $\beta-O-4^{\prime}$ & 85.2 & 85.1 & 85.3 \\
\hline $\mathrm{C}_{\alpha}$ in $\beta-O-4^{\prime}$ & 72.3 & 72.3 & 72.2 \\
\hline$C_{\gamma}$ in $\beta-\beta^{\prime}$ & 71.7 & 71.6 & 71.4 \\
\hline $\mathrm{C}_{\gamma}$ in $\beta-O-4^{\prime}$ & 60.1 & 60.0 & 59.7 \\
\hline
\end{tabular}

$\mathrm{S}_{2 / 6}$ was found at $\delta_{\mathrm{C}} / \delta_{\mathrm{H}} 103.0 / 6.6 \mathrm{ppm}$. Cross peak from $\mathrm{C}_{2 / 6} /$ $\mathrm{H}_{2 / 6}$ in oxidized $\mathrm{C} \alpha=\mathrm{O}$ was shifted to $\delta_{\mathrm{C}} / \delta_{\mathrm{H}} 106.0 / 7.3 \mathrm{ppm}$. Condensed $S\left(\delta_{\mathrm{C}} / \delta_{\mathrm{H}} 106.6 / 6.5 \mathrm{ppm}\right)$ unit was observed in NO.1 and NO.3 lignin fractions, while the signal from condensed $G$ $\left(\delta_{\mathrm{C}} / \delta_{\mathrm{H}} 113.4 / 6.7 \mathrm{ppm}\right)$ was found only in ethanol-extractable lignin fraction. For relative abundance analysis of the lignin subunits in this region, the range of $\delta_{\mathrm{C}} / \delta_{\mathrm{H}} 113-109 / 7.6-6.8 \mathrm{ppm}$ was used as the internal standard (Zeng et al., 2013). The ${ }^{13} \mathrm{C}-{ }^{1} \mathrm{H}$ correlation for $\mathrm{S}_{2 / 6}$ at $\delta_{\mathrm{C}} / \delta_{\mathrm{H}} 103.0 / 6.6 \mathrm{ppm}, \mathrm{G}_{2}$ at $\delta_{\mathrm{C}} / \delta_{\mathrm{H}}$ 111.0/6.9 ppm, $\mathrm{H}_{2 / 6}$ at $\delta_{\mathrm{C}} / \delta_{\mathrm{H}} 128.0 / 7.2 \mathrm{ppm}$, and $p \mathrm{CA}_{2 / 6}$ at $\delta_{\mathrm{C}} / \delta_{\mathrm{H}} 130.0 / 7.4 \mathrm{ppm}$ were used for volume integration of the $\mathrm{S}$, 


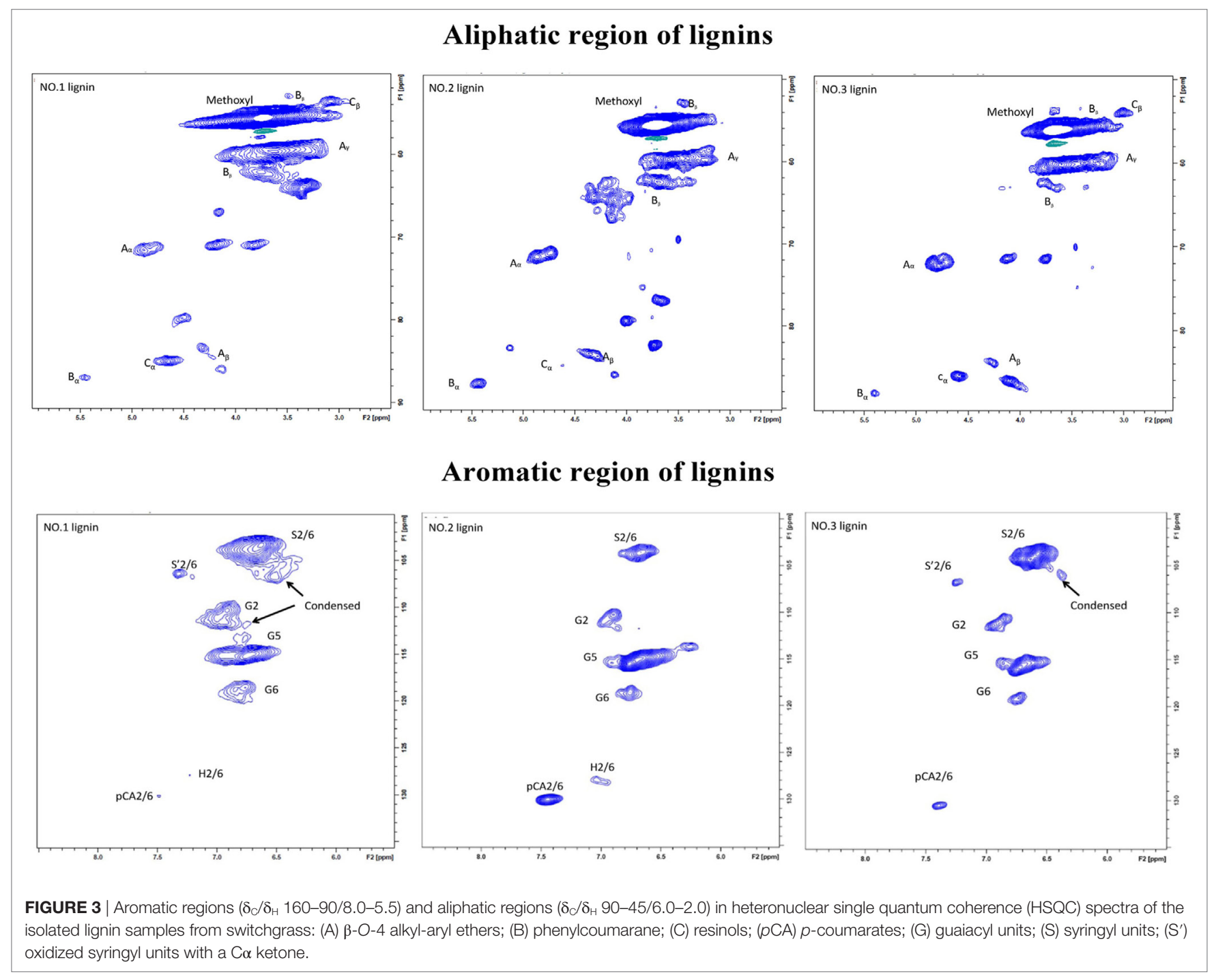

$\mathrm{G}, \mathrm{H}$, and $p$-coumaric acid ( $p \mathrm{CA}$ ) moieties. Analysis results by a combination of ${ }^{13} \mathrm{C}$ NMR and 2D-HSQC NMR were also shown and the results were expressed as number of specific subunit per 100 aromaitc rings (Ar). As presented in Table 4, the relative content of S unit was the highest in NO.3 lignin (62.8/100 Ar and $74.8 \%$ ) and the lowest in NO.2 lignin (22.0/100 Ar and $36.6 \%$ ), while the relative content of $\mathrm{G}$ unit in those samples was decreased in the order of NO.1 lignin (34.6/100 Ar) $>$ NO.2 lignin $(28.2 / 100 \mathrm{Ar})>$ NO.3 lignin (23.1/100 Ar). The S/G ratios of the three lignin fractions were 1.4, 0.7, and 2.9 for NO.1 lignin, NO.2 lignin, and NO.3 lignin, respectively. H units were mainly found in NO.2 lignin fraction (96\% dioxane extraction). Previous studies showed that $p C A$ was formed via lignification of $p$-coumarolyated monolignols and acylated at $\gamma$-OH (Del et al., 2012; Zeng et al., 2013), which was mostly contained in NO.2 lignin (12.0/100 Ar), followed by NO.3 (3.1/100 Ar) and NO.1 (0.4/100 Ar) lignin.

The $\mathrm{C}-\mathrm{H}$ correlations of methoxyl group $\left(-\mathrm{OCH}_{3}\right), \beta-\mathrm{O}-4$, $\beta-5$, and $\beta-\beta$ were observed in the aliphatic region. For the quantitative analysis of the lignin subunits in this region, the range of $\delta_{\mathrm{C}} / \delta_{\mathrm{H}} 88-82 / 5.6-3.9 \mathrm{ppm}$ was used as the internal standard (Zeng et al., 2013). Signals from $\mathrm{C} \alpha / \mathrm{H} \alpha$ in $\beta-O-4$ linkage at $\delta_{\mathrm{C}} / \delta_{\mathrm{H}} 72.0 / 4.8 \mathrm{ppm}, \mathrm{C} \alpha / \mathrm{H} \alpha$ in phenylcoumaran $(\beta-5)$ substructure at $\delta_{\mathrm{C}} / \delta_{\mathrm{H}} 87.0 / 5.4 \mathrm{ppm}, \mathrm{C} \alpha / \mathrm{H} \alpha$ in resinol $(\beta$ $\beta$ ) substructure at $\delta_{\mathrm{C}} / \delta_{\mathrm{H}} 85.0 / 4.6 \mathrm{ppm}$ were used to represent the total linkages. The analysis results showed that $\beta-O-4$ was the dominant interunit linkages in the lignin fractions, which accounted for $61.7,73.1$, and $76.4 \%$ for NO.1, NO.2, and NO.3 lignin fraction, respectively. NO.2 lignin had the highest $\beta$ O-4 content (18.6/100 Ar), while NO.3 lignin had the lowest (8.6/100 Ar). The same trend could also be found in the content of phenylcoumaran linkages. More resinol linkages were observed than phenylcoumaran linkages in NO.1 and NO.3 lignin fractions, while phenylcoumaran linkages were more abundant than resinol in NO.2 lignin.

\section{${ }^{31}$ P-NMR Determination}

For the quantitative analysis of hydroxyl group $(-\mathrm{OH})$ in each lignin fraction, ${ }^{31} \mathrm{P}$ NMR analysis was conducted as described in previous study (Pu et al., 2011). Quantitative analysis results of 
TABLE 4 | Nuclear magnetic resonance analysis results of three lignin samples fractionated from dilute acid pretreated switchgrass.

\begin{tabular}{|c|c|c|c|c|c|c|}
\hline \multirow[t]{2}{*}{ Lignin substructure } & \multicolumn{2}{|c|}{ NO.1 lignin } & \multicolumn{2}{|c|}{ NO.2 lignin } & \multicolumn{2}{|c|}{ NO.3 lignin } \\
\hline & $\mathrm{Ar}^{\mathrm{a}}$ & $\%^{b}$ & $\mathrm{Ar}^{\mathrm{a}}$ & $\%^{\mathrm{b}}$ & $A r^{a}$ & $\%^{\mathrm{b}}$ \\
\hline S & $48.5 \pm 0.01$ & $58.0 \pm 0.03$ & $22.0 \pm 0.04$ & $36.6 \pm 0.02$ & $64.8 \pm 0.24$ & $74.8 \pm 0.02$ \\
\hline $\mathrm{G}$ & $34.6 \pm 0.05$ & $41.7 \pm 0.03$ & $28.2 \pm 0.03$ & $53.2 \pm 0.04$ & $23.1 \pm 0.63$ & $25.2 \pm 0.02$ \\
\hline $\mathrm{H}$ & $0.3 \pm 0.01$ & $0.3 \pm 0.00$ & $6.4 \pm 0.04$ & $0.11 \pm 0.01$ & 0 & 0 \\
\hline$p$-coumaric acid (pCA) & $0.4 \pm 0.00$ & $0.7 \pm 0.00$ & $12.0 \pm 0.08$ & $21.9 \pm 0.01$ & $3.1 \pm 0.02$ & $3.7 \pm 0.00$ \\
\hline$S / G$ & $1.4 \pm 0.01$ & $1.4 \pm 0.08$ & $0.8 \pm 0.01$ & $0.7 \pm 0.00$ & $2.8 \pm 0.06$ & $2.9 \pm 0.07$ \\
\hline$\beta-O-4$ & $10.4 \pm 0.01$ & $61.7 \pm 0.01$ & $18.6 \pm 0.04$ & $73.1 \pm 0.04$ & $8.6 \pm 0.10$ & $76.4 \pm 0.02$ \\
\hline$\beta-5$ & $1.7 \pm 0.03$ & $11.0 \pm 0.01$ & $8.3 \pm 0.01$ & $25.4 \pm 0.02$ & $1.1 \pm 0.04$ & $9.1 \pm 0.02$ \\
\hline$\beta-\beta$ & $4.5 \pm 0.01$ & $27.3 \pm 0.01$ & $0.6 \pm 0.03$ & $1.5 \pm 0.01$ & $1.7 \pm 0.03$ & $14.5 \pm 0.01$ \\
\hline
\end{tabular}

${ }^{a}$ Amount of specific functional group was expressed as number per $100 \mathrm{Ar}$.

${ }^{b}$ Amount of specific functional group was expressed as percentage of $S+G+H$ for $S, G, H$, and $p C A$, of total side chain for $\beta-O-4, \beta-5$, and $\beta-\beta$.

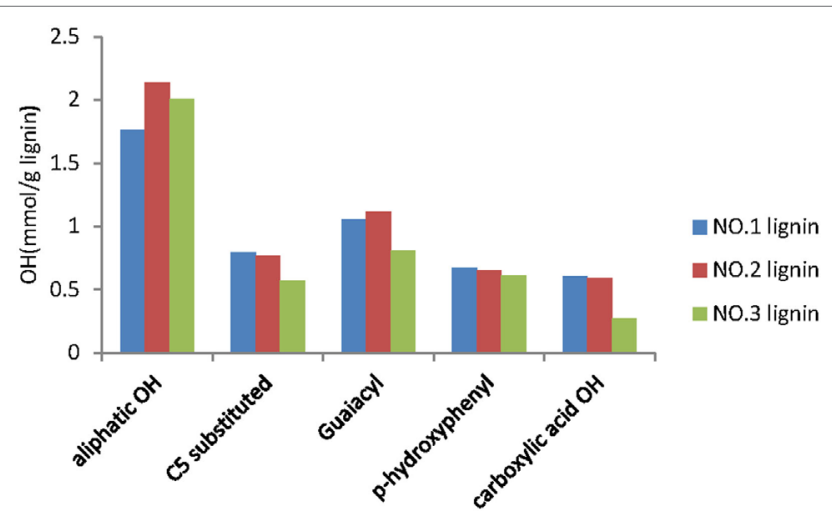

FIGURE $4 \mid{ }^{31}$ P-NMR spectra analysis results of lignin fractions from dilute acid pretreated switchgrass.

$\mathrm{OH}$ groups in the lignin fractions were presented in Figure 4. The results clearly showed that the aliphatic hydroxyl group was a major hydroxyl group in the three lignin fractions. This was in accordance with the previously reported results, which stated that the dominant hydroxyl groups from lignin of switchgrass after acidic pretreatment were at aliphatic site (Samuel et al., 2010). The NO.2 lignin fraction has the most aliphatic $\mathrm{OH}$ content $(2.14 \mathrm{mmol} / \mathrm{g})$ and the least $\mathrm{C} 5$ substituted $\mathrm{OH}$ $(0.57 \mathrm{mmol} / \mathrm{g})$, while the NO.1 fraction has the least aliphatic $\mathrm{OH}$ content $(1.76 \mathrm{mmol} / \mathrm{g})$ and the most $\mathrm{C} 5$ substituted $\mathrm{OH}$ content $(0.79 \mathrm{mmol} / \mathrm{g})$. The contents of other groups from the three lignin fractions were similar, except that the carboxylic acid $\mathrm{OH}$ in the NO.3 lignin was only half of that in the other two lignin fractions. Similar results have been previously reported, which indicated that lignin fraction with high molecular weight contains high aliphatic $\mathrm{OH}$ and low phenolic $\mathrm{OH}$ (Sadeghifar et al., 2017).

\section{CBH Adsorption to Lignins by Langmuir Equation}

It was reported that binding ability of lignin to enzymes can represent the binding capacity of lignin in the biomass (Sun et al., 2016). In this study, the binding ability between the isolated lignin fractions and $\mathrm{CBH}$ was measured by determining the Langmuir
TABLE 5 | Langmuir adsorption isotherm parameters from $\mathrm{CBH}$ adsorption to lignins.

\begin{tabular}{lcccc}
\hline & $\begin{array}{c}\boldsymbol{E}_{\max } \\
\mathbf{m g} / \mathbf{g}\end{array}$ & $\begin{array}{c}\boldsymbol{K}_{\text {ads }} \\
\mathbf{m l} / \mathbf{m g}\end{array}$ & $\begin{array}{c}\text { Binding strength } \\
\mathbf{m l} / \mathbf{g} \text { lignin }\end{array}$ & $\boldsymbol{R}^{\mathbf{2}}$ \\
\hline N0.1 lignin & 7.63 & 4.08 & 31.13 & 0.94 \\
NO.2 lignin & 5.53 & 3.34 & 18.47 & 0.99 \\
N0.3 lignin & 12.32 & 4.92 & 60.61 & 0.99 \\
\hline
\end{tabular}

adsorption isotherms of $\mathrm{CBH}$ onto the isolated lignins. The results are shown in Table 5. The adsorption data fitted well with the Langmuir isotherm. The maximum adsorptions of $\mathrm{CBH}$ were $7.63,5.53$, and $12.32 \mathrm{mg} / \mathrm{g}$ for the three lignin fractions, which were similar to the literature (Pareek et al., 2013; Zheng et al., 2013; Machado et al., 2015; Lu et al., 2016; Sun et al., 2016). It should be noted that the binding results could be affected by the different lignin isolation/pretreatment conditions, enzyme and test conditions (temperatures, lignin loading) used for determination. The highest binding strength was observed for NO.3 lignin $(60.61 \mathrm{ml} / \mathrm{g})$, followed by NO.1 (31.13 ml/g) lignin and NO.2 lignin $(18.47 \mathrm{ml} / \mathrm{g})$. The variations in the adsorption results for the lignin faction samples might be due to the different structural characteristics.

\section{The Relationship between Lignin Structural Characteristic and Non- Productive Enzyme Adsorption Factors}

In order to identify the responsible functional groups for the adsorption ability of different lignin samples, the content of different specific groups in lignins was correlated with the corresponding adsorption results. Positive associations were observed between the percentage of $S$ units and the adsorption capacity $\left(y=0.1493 x+2.8231, R^{2}=0.99\right), K_{\mathrm{ads}}$ $\left(y=0.0509 x+1.4104, R^{2}=0.90\right)$ and binding strength $\left(y=1.2773 x-31.129, R^{2}=0.76\right)$. Similar correlations was also found between number of $S$ units/100 Ar and binding parameters, suggesting that higher content of $S$ unit in isolated lignin resulted in more adsorbed $\mathrm{CBH}$. In contrast, negative correlations were observed between the content of $\mathrm{G}$ unit and the adsorption parameters $\left(E_{\max }: y=-0.725 \mathrm{x}+28.745\right.$, $R^{2}=0.92 ; K_{\text {ads }}: y=-0.056 x+6.357, R^{2}=0.99$; binding 
strength: $\left.y=-1.5246 x+97.77, R^{2}=0.98\right)$. For the $\mathrm{S} / \mathrm{G}$ ratio, we also observed positive correlations with maximum adsorption capacity $\left(y=3.1233 x+3.7043, R^{2}=0.99\right), K_{\text {ads }}$ $\left(y=0.6931 x+2.9581, R^{2}=0.97\right)$, and binding strength $\left(y=19.234 x+4.6808, R^{2}=0.99\right)$. Similarly, Tan and coworkers (Tan et al., 2015) observed that the milled wood lignin from bisulfite pretreated oil palm empty fruit bunch with a higher $\mathrm{S} / \mathrm{G}$ ratio showed higher enzyme adsorption. In addition, negative correlations of guaiacyl $\mathrm{OH}$ content with maximum adsorption capacity $\left(y=-21.135 x+29.475, R^{2}=0.98\right), K_{\text {ads }}$ $\left(y=-4.6209 x+8.7006, R^{2}=0.91\right)$ and binding strength $\left(y=-131.61 x+167.39, R^{2}=0.99\right)$ were found.

The effect of molecular weights and uniformity in lignin fragment size on the cellulase binding has been studied before (Guo et al., 2014; Tan et al., 2015). Among the three lignin fractions from dilute acid pretreated switchgrass, lignin with higher PDI absorbed less $\mathrm{CBH}$ during the binding process. It indicated that lignin with more uniform fragment size tends to have stronger binding ability on cellulase. Previous research also reported that PDI was inversely related to the interaction of the lignin with the cellulase (Berlin et al., 2006; Pareek et al., 2013).

Better understanding of the mechanism of cellulase adsorption to lignin is beneficial to the bioethanol production process. It is possible to make modification to lignin accordingly and choose proper pretreatment techniques to reduce the nonproductive binding of cellulase to lignin and make the whole process economically feasible. The results indicates that lower $\mathrm{S} / \mathrm{G}$ ratio in the the pretreated switchgrass lignin has lower non-productive enzyme binding, which could be favorable for enzymatic hydrolysis.

\section{CONCLUSION}

To obtain lignin with different physicochemical characteristics, three lignin fractions were extracted from diluted acid pretreated switchgrass. Each lignin fraction was found to have different structural characteristic and adsorption ability to $\mathrm{CBH}$ from Trichoderma longibrachiatum. It was found that the monolignol composition of syringyl, guaiacyl units, and S/G ratio in switchgrass lignin had correlation with the adsorption ability of lignin and binding strength of $\mathrm{CBH}$. Lignin with lower S/G ratio appeared to have less effect on the $\mathrm{CBH}$ adsorption.

\section{REFERENCES}

Abraham, R., Verma, M., Barrow, C., and Puri, M. (2014). Suitability of magnetic nanoparticle immobilized cellulases in enhancing enzymatic saccharification of pretreated hemp biomass. Biotechnol. Biofuels 7, 90-101. doi:10.1186/1754-6834-7-90

Benjamin, Y., Cheng, H., and Görgens, J. (2013). Evaluation of bagasse from different varieties of sugarcane by diluteacid pretreatment and enzymatic hydrolysis. Ind. Crops Prod. 51, 7-18. doi:10.1016/j.indcrop.2013.08.067

Berlin, A., Balakshin, M., Gilkes, N., Kadla, J., Maximenko, V., Kubo, S., et al. (2006). Inhibition of cellulase, xylanase and $\beta$-glucosidase activities by softwood lignin preparations. J. Biotechnol. 125, 198-209. doi:10.1016/j.jbiotec. 2006.02.021

Björkman, A. (1956). Studies on finely divided wood. Part 1.-Extraction of lignin with neutral solvent. Sven. Papperstidn 59, 477-485.

\section{AUTHOR CONTRIBUTIONS}

LY and HY performed the research, data analysis and drafted the manuscript. CY, XM, ML, and NH carried out the NMR experiments and revised the manuscript draft. YP and AR analyzed the data and revised the manuscript. All authors read and approved the final manuscript.

\section{ACKNOWLEDGMENTS}

LY and HY are grateful for the support by National Natural Science Foundation of China (No. 31500496), China Scholarship Council (NO. 2011842330 and NO. 201508420257) and Key Laboratory of Pulp and Paper Science \& Technology of Ministry of Education of China (NO. KF-201719 and NO. KF201611), State Key Laboratory of Pulp and Paper Engineering (No. 201510), key project of Hubei Provincial Department of Education (NO.D20161402) and Foundation (No. 201611B01) of Hubei Provincial Key Laboratory of Green Materials for Light Industry. This manuscript has been authored and partially supported by UT-Battelle, LLC under Contract No. DE-AC05-00OR22725 with the U.S. Department of Energy. This study was supported and performed as part of the BioEnergy Science Center (BESC). The BESC is a U.S Department of Energy Bioenergy Research Center supported by the Office of Biological and Environmental Research in the DOE Office of Science. The United States Government retains and the publisher, by accepting the article for publication, acknowledges that the United States Government retains a non-exclusive, paidup, irrevocable, world-wide license to publish or reproduce the published form of this manuscript, or allow others to do so, for United States Government purposes. The Department of Energy will provide public access to these results of federally sponsored research in accordance with the DOE Public Access Plan (http:// energy.gov/downloads/doe-public-access-plan). The views and opinions of the authors expressed herein do not necessarily state or reflect those of the United States Government or any agency thereof. Neither the United States Government nor any agency thereof, nor any of their employes, makes any warranty, expressed or implied, or assumes any legal liability or responsibility for the accuracy, completeness, or usefulness of any information, apparatus, product, or process disclosed, or represents that its use would not infringe privately owned rights.

Cao, S., Pu, Y., Studer, M., Wyman, C., and Ragauskas, A. J. (2012). Chemical transformations of Populustrichocarpa during dilute acid pretreatment. RSC Adv. 29, 10925-10936. doi:10.1039/c2ra22045h

Capanema, E., Balakshin, M., and Kadla, J. (2004). A comprehensive approach for quantitative lignin characterization by NMR spectroscopy. J. Agric. Food Chem. 52, 1850-1860. doi:10.1021/jf035282b

Del, J., Rencoret, J., Prinsen, P., Martinez, A., Ralph, J., and Gutierrez, A. (2012). Structural characterization of wheat straw lignin as revealed by analytical pyrolysis, 2D-NMR, and reductive cleavage methods. J. Agric. Food Chem. 60, 5922-5935. doi:10.1021/jf301002n

Galbe, M., and Zacchi, G. (2007). Pretreatment of lignocellulosic materials for efficient bioethanol production. Adv. Biochem. Eng. Biotechnol. 108, 41-65. doi:10.1007/10_2007_070

Guo, F., Shi, W., Sun, W., Li, X., Wang, F., Zhao, J., et al. (2014). Differences in the adsorption of enzymes onto lignins from diverse types of lignocellulosic 
biomass and the underlying mechanism. Biotechnol. Biofuels 7, 38-47. doi:10.1186/1754-6834-7-38

Hao, N., Lu, K., Ben, H., Adhikari, S., Lacerda, B., and Ragauskas, A. J. (2017). Effect of autohydrolysis pretreatment conditions on sugarcane bagasse structures and product distribution resulting from pyrolysis. Energy Technol. 5, 1-10. doi:10.1002/ente.201700490

Hu, G., Cateto, C., Pu, Y., Samuel, R., and Ragauskas, A. (2012). Structural characterization of switchgrass lignin after ethanol organosolv pretreatment. Energy Fuels 26, 740-745. doi:10.1021/ef201477p

Igarashi, K., Koivula, A., Wada, M., Kimura, S., Penttilä, M., and Samejima, M. (2009). High speed atomic force microscopy visualizes processive movement of Trichoderma reesei cellobiohydrolase I on crystalline cellulose. J. Biol. Chem. 284, 36186-36190. doi:10.1074/jbc.M109.034611

Kubicek, C., Bölzlbauer, U., Kovacs, W., Mach, R., Kuhls, K., Lieckfeldt, E., et al. (1996). Cellulase formation by species of Trichoderma sect. Longibrachiatum and of Hypocrea spp. with anamorphs referable to Trichoderma sect. Longibrachiatum. Fungal Genet. Biol. 20, 105-114. doi:10.1006/fgbi.1996.0025

Kumar, R., Hu, F., Hubbell, C. A., Ragauskas, A. J., and Wyman, C. E. (2013). Comparison of laboratory delignification methods, their selectivity, and impacts on physiochemical characteristics of cellulosic biomass. Bioresour. Technol. 130, 372-381. doi:10.1016/j.biortech.2012.12.028

Li, H., Pu, Y., Kumar, R., Ragauskas, A., and Wyman, C. (2014). Investigation of lignin deposition on cellulose during hydrothermal pretreatment, its effect on cellulose hydrolysis, and underlying mechanisms. Biotechnol. Bioeng. 111, 485-492. doi:10.1002/bit.25108

Li, P., Liu, Y., Lu, J., Yang, R., Li, H., and Wang, H. (2016). Structural characterization and effect on enzymatic hydrolysis of milled wood lignin isolated from reed straw and corn stover pretreated with liquid hot water. BioResources 11, 8777-8790. doi:10.15376/biores.11.4.8777-8790

Lu, X., Zheng, X., Li, X., and Zhao, J. (2016). Adsorption and mechanism of cellulase enzymes onto lignin isolated from corn stover pretreated with liquid hot water. Biotechnol. Biofuels 9, 118-129. doi:10.1186/s13068-016-0531-0

Machado, D., NetoJoão, M., Pradella, J., Bonomi, A., and Aline, C. (2015). Adsorption characteristics of cellulase and $\beta$-glucosidase on Avicel, pretreated sugarcane bagasse, and lignin. Biotechno. Appl. Biochem. 62, 681-689. doi:10.1002/bab.1307

Martín, R., Rahikainen, J., Johansson, L., Marjamaa, K., Laine, J., Kruus, K., et al. (2013). Preferential adsorption and activity of monocomponent cellulases on lignocellulose thin films with varying lignin content. Biomacromolecules 14, 1231-1239. doi:10.1021/bm400230s

Meng, X., Foston, M., Leisen, J., DeMartini, J., Wyman, C. E., and Ragauskas, A. J. (2013). Determination of porosity of lignocellulosic biomass before and after pretreatment by using Simons' stain and NMR techniques. Bioresour. Technol. 144, 467-476. doi:10.1016/j.biortech.2013.06.091

Mesa, L., Martínez, Y., Barrio, E., and González, E. (2017). Desirability function for optimization of dilute acid pretreatment of sugarcane straw for ethanol production and preliminary economic analysis based in three fermentation configurations. Appl. Energ. 198, 299-311. doi:10.1016/j.apenergy.2017. 03.018

Mörck, R., Reimann, A., and Kringstad, K. (1988). Fractionation of kraft lignin by successive extraction with organic solvents. III. Fractionation of kraft lignin from birch. Holzforschung 42, 111-116. doi:10.1515/hfsg.1988.42.2.111

Mörck, R., Yoshida, H., and Kringstad, K. (1986). Fractionation of kraft lignin by successive extraction with organic solvents. 1. Functional groups, ${ }^{13} \mathrm{C}-\mathrm{NMR}-$ spectra and molecular weight distributions. Holzforschung 42, 51-60.

Palonen, H., Tjerneld, F., Zacchi, G., and Tenkanen, M. (2004). Adsorption of Trichoderma reesei CBH I and EG II and their catalytic domains on steam pretreated softwood and isolated lignin. J. Biotechnol. 107, 65-72. doi:10.1016/j. jbiotec.2003.09.011

Pareek, N., Gillgren, T., and Jösson, L. (2013). Adsorption of proteins involved in hydrolysis of lignocellulose on lignins and hemicelluloses. Bioresour. Technol. 148, 70-77. doi:10.1016/j.biortech.2013.08.121

$\mathrm{Pu}$, Y., Cao, S., and Ragauskas, A. J. (2011). Application of quantitative ${ }^{31} \mathrm{P}$ NMR in biomass lignin and biofuel precursors characterization. Energy Environ. Sci. 4, 3154-3166. doi:10.1039/C1EE01201K

Ragauskas, A., Beckham, G., Biddy, M., Chandra, R., Chen, F., Davis, M., et al. (2014). Lignin valorization: improving lignin processing in the biorefinery. Science 344, 709-718. doi:10.1126/science.1246843

Rahikainen, J., Evans, J., Mikander, S., Kalliola, A., Puranen, T., Tamminen, T., et al. (2013). Cellulase-lignin interactions-the role of carbohydrate-binding module and $\mathrm{pH}$ in non-productive binding. Enzyme Microb. Technol. 53, 315-321. doi:10.1016/j.enzmictec.2013.07.003

Ralph,J., Bunzel, M., Marita,J., Hatfield, R., Lu, F., Kim, H., etal.(2004). Peroxidasedependent cross-linking reactions of phydroxycinnamates in plant cell walls. Phytochem. Rev. 3, 79-96. doi:10.1023/B:PHYT.0000047811.13837.fb

Sadeghifar, H., Wells, T., Le, R., Sadeghifar, F., Yuan, J., and Ragauskas, A. (2017). Fractionation of organosolv lignin using acetone: water and properties of the obtained fractions. ACS Sustainable Chem. Eng. 5, 580-587. doi:10.1021/ acssuschemeng.6b01955

Saini, J., Patel, A., Adsul, M., and Singhania, R. (2016). Cellulase adsorption on lignin: a roadblock for economic hydrolysis of biomass. Renew. Energy 98, 29-42. doi:10.1016/j.renene.2016.03.089

Samuel, R., Pu, Y., Raman, B., and Ragauskas, A. J. (2010). Structural characterization and comparison of switchgrass ball-milled lignin before and after dilute acid pretreatment. Appl. Biochem. Biotechnol. 162, 62-74. doi:10.1007/ s12010-009-8749-y

Sluiter, A., Hames, B., Ruiz, R., Scarlata, C., Sluiter, J., Templeton, D., et al. (2008). Determination of Structural Carbohydrates and Lignin in Biomass. Technical Report No. TP-510-42618. Golden, CO: National Renewable Energy Laboratory. Available at: https://www.nrel.gov/docs/gen/fy13/42618.pdf

Strobel, K., Pfeiffer, K., Blanch, H., and Clark, D. (2015). Structural insights into the affinity of Cel7a carbohydrate-binding module for lignin. J. Biol. Chem. 290, 22818-22826. doi:10.1074/jbc.M115.673467

Strobel, K., Pfeiffer, K., Blanch, H., and Clark, D. (2016). Engineering Cel7A carbohydrate binding module and linker for reduced lignin inhibition. Biotechnol. Bioeng. 113, 1369-1374. doi:10.1002/bit.25889

Sun, S., Huang, Y., Sun, R., and Tu, M. (2016). Strong association of condensed phenolic moieties in isolated lignins with their inhibition of enzymatic hydrolysis. Green Chem. 18, 4276-4286. doi:10.1039/C6GC00685J

Tan, L., Sun, W., Li, X., Zhao, J., Qu, Y., Choo, Y., et al. (2015). Bisulfite pretreatment changes the structure and properties of oil palm empty fruit bunch to improve enzymatic hydrolysis and bioethanol production. Biotechnol. J. 10, 915-925. doi:10.1002/biot.201400733

Yan, J., Hu, Z., Pu, Y., Brummer, C., and Ragauskas, A. J. (2010). Chemical compositions of four switchgrass populations. Biomass Bioenergy 34, 48-53. doi:10.1016/j.biombioe.2009.09.010

Yan, S., Li, T., and Yao, L. (2011). Mutational effects on the catalytic mechanism of cellobiohydrolase I from Trichoderma reesei. J. Phys. Chem. B 115, 4982-4989. doi:10.1021/jp200384m

Yang, H., Xie, Y., Zheng, X., Pu, Y., Huang, F., Meng, X., et al. (2016). Comparative study of lignin characteristics from wheat straw obtained by soda-AQ and kraft pretreatment and effect on the following enzymatic hydrolysis process. Bioresour. Technol. 207, 361-369. doi:10.1016/j.biortech.2016.01.123

Yao, L., Yang, H., Yoo, C. G., Meng, X., Li, M., Pu, Y., et al. (2017). Adsorption of cellobiohydrolases I onto lignin fractions from dilute acidpretreated Broussonetia papyrifera. Bioresour. Technol. 244, 957-962. doi:10.1016/j. biortech.2017.08.024

Yao, L., Yue, J., Zhao, J., Dong, J., Li, X., and Qu, Y. (2010). Application of acidic wastewater from monosodium glutamate process in pretreatment and cellulase production for bioconversion of corn stover feasibility evaluation. Bioresour. Technol. 101, 8755-8761. doi:10.1016/j.biortech.2010.04.104

Yoo, C., Li, M., Meng, X., Pu, Y., and Ragauskas, A. J. (2017). Effects of organosolv and ammonia pretreatments. Green Chem. 19, 2006-2016. doi:10.1039/ C6GC03627A

Yu, Z., Gwak, K., Treasure, T., Jameel, H., Chang, H., and Park, S. (2014). Effect of lignin chemistry on the enzymatic hydrolysis of woody biomass. Chem. Sus. Chem. 7, 1942-1950. doi:10.1002/cssc.201400042

Yuan, T., He, J., Xu, F., and Sun, R. (2009). Fractionation and physico-chemical analysis of degraded lignins from the black liquor of Eucalyptus pellita KP-AQ pulping. Polym. Dgrade. Stabil. 94, 1142-1150. doi:10.1016/j. polymdegradstab.2009.03.019

Zeng, J., Helms, G., Gao, X., and Chen, S. (2013). Quantification of wheat straw lignin structure by comprehensive NMR analysis. J. Agric. Food Chem. 61, 10848-10857. doi:10.1021/jf4030486

Zeng, Y., Zhao, S., Yang, S., and Ding, S. (2014). Lignin plays a negative role in the biochemical process for producing lignocellulosic biofuels. Curr. Opin. Biotechnol. 27, 38-45. doi:10.1016/j.copbio.2013.09.008

Zheng, Y., Zhang, S., Miao, S., Su, Z., and Wang, P. (2013). Temperature sensitivity of cellulase adsorption on lignin and its impact on enzymatic hydrolysis of lignocellulosic biomass. J. Biotechnol. 166, 135-143. doi:10.1016/j.jbiotec.2013.04.018 
Zhou, X., Xu, J., Wang, Z., Cheng, J., Li, R., and Qu, R. (2012). Dilute sulfuric acid pretreatment of transgenic switchgrass for sugar production. Bioresour. Technol. 104, 823-827. doi:10.1016/j.biortech.2011.11.051

Conflict of Interest Statement: The authors declare that the research was conducted in the absence of any commercial or financial relationships that could be construed as a potential conflict of interest.
Copyright (c) 2018 Yao, Yang, Yoo, Meng, Pu, Hao and Ragauskas. This is an open-access article distributed under the terms of the Creative Commons Attribution License (CC BY). The use, distribution or reproduction in other forums is permitted, provided the original author(s) and the copyright owner are credited and that the original publication in this journal is cited, in accordance with accepted academic practice. No use, distribution or reproduction is permitted which does not comply with these terms. 